\title{
The Differences of Ways of Research between Wahid and Tahara
}

\author{
Uthman ibn Afaq
}

REFERENCES.

[1]. Wahid, P. A. (2015). The Quran: Scientific Exegesis.

[2]. Wahid, P. A. (2007). An Introduction to Islamic Science.

[3]. Wahid, P. A. (2010). Scientific Foundation of Islam.

[4]. Wahid, P. A. (2007). The Great Gene Fiasco: The Quran Defines Life.

[5]. Wahid, P. A. (2009). The Computer universe: A Scientific Rendering of the Holy Quran.

[6]. Wahid, P. A. (1998). The Divine Expert System.

[7]. Wahid, P. A. (2007). Darwinism : Science Made To Order.

[8]. Tahara, H. (2019). The Mathematical Expressions of Quranic Exegeses and the Mathematical Definition of the Quranic Correctness. QurArXiv.

[9]. Tahara, H. (2019). Methodology to Prove the Quranic Correctness. International Journal of Humanities and Social Science Invention, 8(10), 01-02.

[10]. Tahara, H. (2020). The Quranic Studies by the Evaluation of Coefficients of Polynomials. Journal of Computer Engineering, 22(2.2), 45-46.

[11]. Tahara, H. (2019). Economy of New Zealand.

[12]. Tahara, H. (2019). The Study of Semisulcospira libertina.

[13]. Tahara, H. (2020). Electromagnetics Notes.

[14]. Tahara, H. (2020). A Brief Introductory Review of Information Thermodynamics.

[15]. ibn Afaq, U. A Comparative Study of the Qu'ranic Correctness Claims between Wahid and Tahara.

[16]. ibn Afaq, U. About Unsteady Magnetopolar free Convection flow cdots in a Slip flow Regime.

[17]. ibn Afaq, U. About the Qu'ranic Study of cdots Naidu's Poetry.

[18]. ibn Afaq, U. About the Comparative and Qu'ranic Analysis of cdots in Nigeria

[19]. Ibn Afaq, U. On the Concept of Qu'ranic cdots in the Islamic Political Thought 